\title{
Porównanie wiedzy studentów kierunku pielęgniarstwo ze studentami kierunków pozamedycznych na temat wirusowego zapalenia wątroby typu B
}

\section{The knowledge of Hepatitis B - comparison between nursing students and other students of non-medical faculties}

MAGDALENA ZAWIDZKA ${ }^{1}$, ELŻBIETA NAZAR ${ }^{1}$, MARTA KAMIŃSKA $^{1}$, ANNA ANTCZAK-KOMOTERSKA,2

\author{
1 Studenckie Koło Naukowe Nauk o Zdrowiu, Instytut Nauk o Zdrowiu PWSZ \\ we Włocławku, opiekun Koła: dr Beata Haor \\ ${ }^{2}$ Instytut Nauk o Zdrowiu PWSZ we Włocławku \\ DOI: http://dx.doi.org/10.21784/IwP.2018.022 \\ ISSN: 2451-1846
}

\section{Streszczenie:}

Wstęp. Wirusowe zapalenie wątroby typu B to choroba zakaźna wywołana przez wirusa HBV (Hepatitis B Virus). Wirus ten jest około 100 razy bardziej zakaźny niż HIV. Nie rozpoznana choroba przechodzi w stan przewlekły i prowadzi do poważnych powikłań. Istotne ryzyko zakażenia HBV dotyczy pracowników ochrony zdrowia, w tym pielęgniarek, w związku z ekspozycją zawodową.

Cel. Celem badań była analiza wiedzy studentów kierunku pielęgniarstwo oraz innych pozamedycznych kierunków na temat WZW typu B.

Materiał i metody. Badania przeprowadzono wśród 103 studentów kierunku pielęgniarstwo oraz 103 studentów kierunków pozamedycznych. Wykorzystano metodę sondażu diagnostycznego, technikę ankietowania oraz autorski kwestionariusz ankiety. 
Wyniki. Zdecydowana większość studentów kierunku pielęgniarstwo dysponuje prawidłową wiedzą na temat czynników ryzyka zakażenia, profilaktyki i diagnostyki WZW typu B. Wśród studentów innych kierunków widać zdecydowanie niższy poziom wiedzy w zakresie czynników ryzyka zakażenia, profilaktyki oraz diagnostyki WZW typu B.

Wnioski. Studenci kierunku pielęgniarstwo powinni aktywnie uczestniczyć w działaniach i programach profilaktycznych, które mają na celu ograniczenie ryzyka zachorowań na WZW typu B. Świadomość studentów kierunków pozamedycznych powinna być znacznie podwyższona w zakresie czynników ryzyka zakażeniem, profilaktyki oraz diagnostyki WZW typu B.

Słowa kluczowe: HBV, profilaktyka, wiedza

\begin{abstract}
:
Introduction. Hepatitis B is an infectious disease caused by HBV (Hepatitis B Virus). This virus is about 100 times more infectious than HIV. An undiagnosed disease progresses into a chronic condition and leads to serious complications. Health care workers, including nurses, are at risk of HBV infection due to their occupational exposure.

Aim. The aim of the study was to analyze the knowledge of nursing students and other non-medical students on hepatitis B.

Material and methods. The study was conducted among 103 students of nursing and 103 other students of non-medical faculties. The method of diagnostic survey, questionnaire technique and author's questionnaire were used.

Results. The vast majority of nursing students have considerable knowledge of the risk factors for infection, prevention and diagnosis of hepatitis B. Among students of other faculties, there is a significantly lower level of knowledge regarding risk factors for infection, prevention and diagnosis of hepatitis B.

Conclusions. Nursing students should actively participate in preventive activities and programs that aim to reduce the risk of hepatitis B. The awareness of non-medical students should be significantly increased in terms of risk factors for infection, prevention and diagnosis of hepatitis B.
\end{abstract}

Keywords: HBV, prevention, knowledge 


\section{Wstęp}

Wirusowe zapalenie wątroby typu B wywoływane jest przez wirus HBV (Hepatitis B Virus). Prowadzi on do ostrego lub przewlekłego zapalenia wątroby, a w powikłaniach do raka wątrobowokomórkowego i marskości wątroby.

Rozpoznanie zakażenia przewlekłego następuje zazwyczaj przypadkowo, np. podczas badań ogólnego stanu zdrowia czy też podczas badania kwalifikacyjnego dawcy krwi. Podwyższona aktywność aminotransferaz sugeruje wykonanie dalszych badań w kierunku potwierdzenia WZW. Najpopularniejszy test diagnostyczny to test enzymoimmunologiczny, ELISA. W surowicy można oznaczyć spośród antygenów - HBsAg i HBeAg oraz spośród przeciwciał antyHBs, anty-HBe, anty-HBc) i anty-HBcIgM. Bardzo ważnym narzędziem diagnostycznym jest biopsja wątroby. Badaniom powinni być poddawane osoby z tzw. grupy zwiększonego ryzyka. Zaliczają się do nich pacjenci wielokrotnie hospitalizowani, poddawani zabiegom chirurgicznym, osoby, którym przetaczano krew lub składniki krwiopochodne, narkomani, pracownicy służby zdrowia, byli lub aktualni więźniowie, osoby posiadające tatuaże, homoseksualiści, promiskuici i inni [1].

Zakazić możemy się poprzez kontakt $\mathrm{z}$ zakażoną krwią ( wystarczy $0,00004 \mathrm{ml}$ krwi), ale także $\mathrm{z}$ wydalinami osoby zakażonej HBV (wydzielina z pochwy, mleko kobiece, mocz)[2]. Nie zakazimy się poprzez codzienne kontakty towarzyskie, np. podawanie rąk, korzystanie z tych samych sztućców i naczyń stołowych [3].

Leczenie przewlekłego zapalenia wątroby nadal jest trudnym problemem. Obecnie stosuje się lek pegylowany interferon alfa (33\% skuteczności) oraz leki antywirusowe np. entekavir, tenofovir, telbivudyna.

W naszym kraju zachorowalność na tę chorobę spadła od chwili wprowadzenia szczepień ochronnych. Dlatego konieczne jest w dalszym ciągu propagowanie i zalecanie tych szczepień wszystkim 
osobom, które nie są objęte szczepieniami obowiązkowymi, a przede wszystkim dzieciom i młodzieży [3].

Celem badań była analiza wiedzy studentów kierunku pielęgniarstwo oraz innych kierunków, takich jak informatyka, zarządzanie, filologia angielska, mechanika i budowa maszyn, nowe media i e-biznes na temat dróg zakażenia oraz profilaktyki WZW typu B.

\section{Materiał i metody}

Badania przeprowadzono wśród 103 studentów kierunku pielęgniarstwo oraz 103 studentów innych kierunków. Wykorzystano metodę sondażu diagnostycznego, technikę ankietowania oraz autorski kwestionariusz ankiety.

\section{Wyniki}

Poniżej zaprezentowano wyniki badań własnych. Wykazują one stan wiedzy studentów kierunku pielęgniarstwo oraz innych kierunków takich jak informatyka, zarządzanie, filologia angielska, mechanika i budowa maszyn, nowe media i e-biznes odnośnie Wirusowego Zapalenia Wątroby typu B.

Tabela 1. Opinie respondentów nt. konsekwencji WZW typu B.

\begin{tabular}{|c|c|c|}
\hline Odpowiedzi & Pielęgniarstwo & Inne kierunki \\
\hline Tak & $83,5 \%$ & $61,2 \%$ \\
\hline Nie & $5,8 \%$ & $28,2 \%$ \\
\hline Nie wiem & $10,7 \%$ & $10,6 \%$ \\
\hline
\end{tabular}

Źródło: wynik badań własnych 
Powyższa tabela 1 przedstawia procentowy rozkład odpowiedzi na pytanie "Czy wirusowe zapalenie wątroby może być przyczyną marskości wątroby i nowotworów złośliwych?". Zdecydowana większość respondentów na kierunku pielęgniarstwo odpowiedziała twierdząco (83,5\%), natomiast niewielki odsetek ankietowanych $(10,7 \%)$ nie był pewny swojej odpowiedzi. Rozwój marskości wątroby i nowotworów złośliwych jako konsekwencję WZWZ typu B zanegowało tylko 5,8\% ankietowanych. Zauważalna większość respondentów innych kierunków ( 61,2\%) zgodziła się z zadanym pytaniem, natomiast nieznaczna grupa ankietowanych $(10,6 \%)$ nie potrafiła udzielić odpowiedzi. Stanowcza grupa respondentów $(28,2 \%)$ zaprzeczyła by wirusowe zapalenie wątroby miało doprowadzić do marskości wątroby i nowotworów złośliwych.

Tabela 2. Opinie respondentów nt. zakażenia WZW typu B przez kontakt z krwią.

\begin{tabular}{|c|c|c|}
\hline Odpowiedzi & Pielęgniarstwo & Inne kierunki \\
\hline Tak & $72,8 \%$ & $61,2 \%$ \\
\hline Nie & $13,6 \%$ & $25,2 \%$ \\
\hline Nie wiem & $13,6 \%$ & $13,6 \%$ \\
\hline
\end{tabular}

Źródło: wynik badań własnych

Powyższa tabela 2 obrazuje procentowy rozkład odpowiedzi na pytanie „Czy do zakażenia wystarczą nawet śladowe ilości krwi, które nie są widoczne gołym okiem?". Odpowiedzi twierdzącej na kierunku pielęgniarstwo udzieliło $72,8 \%$ badanych. Nie był pewien swojego stanowiska w tym zakresie lub zaprzeczył takiej możliwości zakażenia podobny odsetek ankietowanych studentów pielęgniarstwa (odpowiednio po 13,6\%). Respondenci innych kierunków odpowiedzieli twierdząco w 61,2\%, natomiast znaczna grupa badanych( 25,2\%) zanegowała informację, że do zakażenia wystarczą 
niewielkie ilości krwi. Podobnie jak w przypadku studentów pielęgniarstwa, studenci innych kierunków $(13,6 \%)$ nie było pewnych swojej odpowiedzi.

Tabela 3. Opinie respondentów nt. zakażenia WZW typu B w przebiegu zabiegów stomatologicznych.

\begin{tabular}{|c|c|c|}
\hline Odpowiedzi & Pielęgniarstwo & Inne kierunki \\
\hline Tak & $74,8 \%$ & $55,3 \%$ \\
\hline $\mathrm{Nie}$ & $11,6 \%$ & $29,1 \%$ \\
\hline Nie wiem & $13,6 \%$ & $15,6 \%$ \\
\hline
\end{tabular}

Źródło: wynik badań własnych

W przedstawionej tabeli 3 zaprezentowano procentowy rozkład odpowiedzi na pytanie „Czy możemy zakazić się WZW typu B u dentysty, który wykonuje borowanie lub skaling (usuwanie kamienia nazębnego)". Zaprzeczyło takiej możliwości zakażenia $11,7 \%$ ankietowanych studentów pielęgniarstwa. Z kolei 13,6\% nie potrafiła jednoznacznie zająć stanowiska na powyższe pytanie. Zdecydowana większość respondentów na kierunku pielęgniarstwo $(74,8 \%)$ potwierdziła, że do zakażenia HBV może dojść również w czasie zabiegów stomatologicznych. Znaczna grupa badanych $(29,1 \%)$ z innych kierunków zaprzeczyła by wizyta u stomatologa mogła się przyczynić do zakażenia. Świadomość, iż korzystanie z usług dentysty może nieść ze sobą konsekwencje zarażenie się WZW ma 55,3\% ankietowanych. Natomiast $15,6 \%$ badanych nie potrafiła się ustosunkować do zadanego pytania.

Tabela 4. Opinia respondentów nt. zakażenia WZW typu B podczas badań endoskopowych.

4. Czy możemy zakazić się WZW typu B podczas badań 


\begin{tabular}{|l|l|l|}
\hline \multicolumn{3}{|l|}{ endoskopowych? } \\
\hline Odpowiedzi & Pielęgniarstwo & Inne kierunki \\
\hline Tak & $76,7 \%$ & $41,7 \%$ \\
\hline Nie & $7,8 \%$ & $29,15 \%$ \\
\hline Nie wiem & $15,5 \%$ & $29,15 \%$ \\
\hline
\end{tabular}

Źródło: wynik badań własnych

Tabela 4 obrazuje procentowy rozkład odpowiedzi na pytanie ” Czy możemy zarazić się WZW typu B podczas badań endoskopowych?”. Większość badanych $(76,7 \%)$ studentów pielęgniarstwa odpowiedziała twierdząco na pytanie. Z kolei niewielka grupa ankietowanych $(15,5 \%)$ nie potrafiła udzielić jednoznacznej odpowiedzi. Natomiast 7,8\% respondentów zaprzeczyła, że podczas badań endoskopowych istnieje ryzyko zakażenia WZW typu B. W przypadku innych kierunków taka sama ilość badanych nie znała odpowiedzi lub zaprzeczyła by do zakażenia mogło dojść podczas badań endoskopowych (odpowiednio 29,15\%). Natomiast 41,7\% respondentów wiedziało, że diagnostyka endoskopowa może być przyczyną zakażenia WZW.

Tabela 5. Opinia respondentów nt. zakażenia WZW typu B w czasie zabiegów kosmetycznych i fryzjerskich.

\begin{tabular}{|l|l|l|}
\hline \multicolumn{3}{|l|}{ 5. Czy możemy zakazić się WZW typu B u fryzjera i kosmetyczki? } \\
\hline Odpowiedzi & Pielęgniarstwo & Inne kierunki \\
\hline Tak & $83,5 \%$ & $49,5 \%$ \\
\hline Nie & $5,8 \%$ & $34,0 \%$ \\
\hline Nie wiem & $10,7 \%$ & $16,5 \%$ \\
\hline
\end{tabular}

Źródło: wynik badań własnych

Tabela 5 prezentuje procentowy rozkład odpowiedzi na pytanie „Czy możemy zakazić się WZW typu B u fryzjera i kosmetyczki?”. Świadomość zakażenia HBV w salonie kosmetycznym lub fryzjerskim miała grupa 83,5\% respondentów kierunku pielęgniarstwo. Nieznaczny odsetek badanych $(5,8 \%)$ nie potrafił odpowiedzieć 
na powyższe pytanie. $\mathrm{Z}$ kolei $10,7 \%$ badanych nie potrafiła jednoznacznie odpowiedzieć na to pytanie. Studenci innych kierunków(34\%) stanowczo zaprzeczyli by wizyty w salonach kosmetycznych i fryzjerskich przyczyniały się do zakażenia WZW. Blisko połowa $(49,5 \%)$ badanych odpowiedziała twierdząco, natomiast $16,5 \%$ nie potrafiła konkretnie odpowiedzieć na zadane pytanie.

Tabela 6. Opinia respondentów nt. zakażenia WZW typu B w czasie pobierania krwi.

6. Czy możemy zakazić się WZW typu B podczas pobierania krwi i kontaktu z zakażonymi igłami/ strzykawkami?

\begin{tabular}{|l|l|l|}
\hline Odpowiedzi & Pielęgniarstwo & Inne kierunki \\
\hline Tak & $89,3 \%$ & $70,9 \%$ \\
\hline Nie & $1 \%$ & $21,3 \%$ \\
\hline Nie wiem & $9,7 \%$ & $7,8 \%$ \\
\hline
\end{tabular}

Źródło: wynik badań własnych

Powyższa tabela 6 przedstawia procentowy rozkład odpowiedzi na pytanie „Czy możemy zakazić się WZW typu B podczas pobierania krwi i kontaktu z zakażonymi igłami/ strzykawkami?”. Przeważająca grupa badanych $(89,3 \%)$ studentów pielęgniarstwa potwierdziła, że do zakażania może dojść poprzez kontakt z zainfekowanym sprzętem w trakcie pobierania krwi. Niewielki odsetek badanych $(9,7 \%)$ nie potrafił jednoznacznie odpowiedzieć na pytanie. Zaledwie $1 \%$ ankietowanych zaprzeczył takiej możliwości zakażenia HBV. W przypadku respondentów z innych kierunków 21,3\% zaprzeczyło by do zakażenia mogło dojść poprzez obcowanie $\mathrm{z}$ zakażonym sprzętem medycznym. 70, 9\% badanych odpowiedziało twierdząco, natomiast niewielki procent $(7,8 \%)$ nie potrafiło jednoznacznie odpowiedzieć na zadane pytanie. 
Tabela 7. Opinia respondentów nt. zakażenia WZW typu B podczas kichania.

\begin{tabular}{|l|l|l|}
\hline 7. Czy możemy zakazić się WZW typu B przez kichanie? \\
\hline Odpowiedzi & Pielęgniarstwo & Inne kierunki \\
\hline Tak & $34 \%$ & $1 \%$ \\
\hline Nie & $45,6 \%$ & $85,4 \%$ \\
\hline Nie wiem & $20,4 \%$ & $13,6 \%$ \\
\hline
\end{tabular}

Źródło: wynik badań własnych

W powyższej tabeli 7 przedstawiono procentowy rozkład odpowiedzi na pytanie „Czy możemy zakazić się WZW typu B przez kichanie?". Zdaniem 34\% badanych studentów pielęgniarstwa do zakażenia HBV może dojść przez kichanie. Większość respondentów $(45,6 \%)$ nie potwierdziło takiego stanowiska. Natomiast swojej odpowiedzi w powyższym zakresie nie było pewnych $20,4 \%$ ankietowanych. Z kolei w przypadku studentów innych kierunków zaledwie $1 \%$ badanych odpowiedziało twierdząco. Aż 85, 4\% ankietowanych zaprzeczyło by do zakażenia WZW mogło dojść podczas kichania. Nie pewnych swojej odpowiedzi było 13,6\% badanych.

Tabela 8. Opinia respondentów nt. zakażenia WZW typu B. poprzez wspólne korzystanie ze sztućców i naczyń.

8. Czy możemy zakazić się WZW typu B poprzez używanie tych samych talerzy, szklanek czy sztućców co inne osób?

\begin{tabular}{|l|l|l|}
\hline Odpowiedzi & Pielęgniarstwo & Inne kierunki \\
\hline Tak & $38,8 \%$ & $11,7 \%$ \\
\hline Nie & $40,8 \%$ & $75,7 \%$ \\
\hline Nie wiem & $20,4 \%$ & $12,6 \%$
\end{tabular}

Źródło: wynik badań własnych

Tabela 8 pokazuje procentowy rozkład odpowiedzi na pytanie „Czy możemy zakazić się WZW typu B poprzez używanie tych samych 
talerzy, szklanek czy sztućców co inne osoby ?". Pytanie to sprawiło największy problem respondentom wszystkich kierunków. Potwierdziło możliwość zakażenia HBV w takiej sytuacji 38,8\% badanych studentów pielęgniarstwa, a zaprzeczyło 40,8\% ankietowanych. Z kolei 20,4\% studentów nie potrafiła wskazać konkretnej odpowiedzi. W przypadku innych kierunków twierdząco odpowiedziało $11,7 \%$ badanych, natomiast podane stwierdzenie zanegowało 75,7 \% respondentów. 12,6 \% ankietowanych nie potrafiła jednoznacznie odpowiedzieć na zadane pytanie.

Tabela 9. Opinia respondentów nt. zakażenia WZW typu B poprzez kontakt $\mathrm{z}$ uszkodzonym naskórkiem, błoną śluzową i krwią.

9. Czy możemy zakazić się WZW typu B poprzez kontakt z uszkodzonym naskórkiem, krwią i błonami śluzowymi?

\begin{tabular}{|l|l|l|}
\hline Odpowiedzi & Pielęgniarstwo & Inne kierunki \\
\hline Tak & $83,5 \%$ & $69,9 \%$ \\
\hline Nie & $4,9 \%$ & $22,3 \%$ \\
\hline Nie wiem & $11,6 \%$ & $8,8 \%$ \\
\hline
\end{tabular}

Źródło: wynik badań własnych

W przedstawionej tabeli 9 zaprezentowano procentowy rozkład odpowiedzi na pytanie „Czy możemy zakazić się WZW typu B poprzez kontakt z uszkodzonym naskórkiem, krwią i błonami śluzowymi?”. Przeważająca grupa ankietowanych studentów pielęgniarstwa $(83,5 \%)$ potwierdziła, że do zakażenia HBV może dojść w czasie wskazanych w pytaniu sytuacji. Tylko 4,9\% badanych zaprzeczyła takiej możliwości. Natomiast $11,7 \%$ badanych nie potrafiło udzielić jednoznacznej odpowiedzi. Natomiast w przypadku studentów innych kierunków 69,9\% respondentów udzieliło odpowiedzi twierdzącej. Niespełna 8,8 \% ankietowanych nie potrafiła udzielić konkretnej odpowiedzi, a 22,3\% badanych zaprzeczyło by mogło dojść do takiej sytuacji. 
Tabela 10. Opinia respondentów nt. zakażenia WZW typu B podczas stosunku seksualnego.

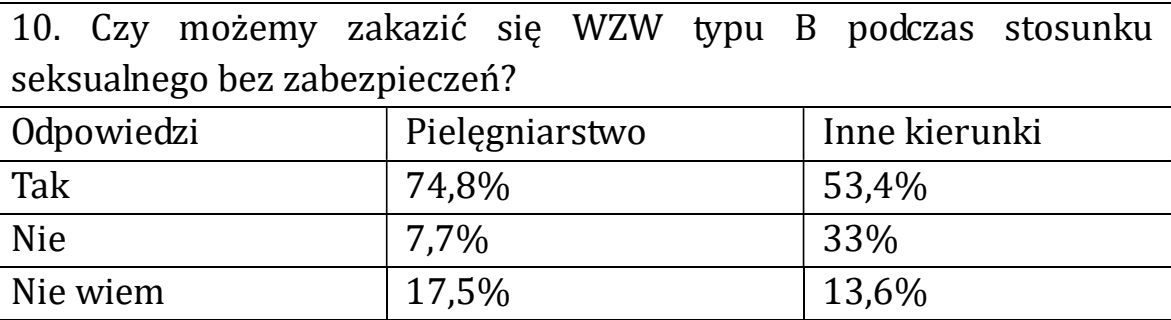

Źródło: wynik badań własnych

Tabela 10 obrazuje procentowy rozkład odpowiedzi na pytanie " Czy możemy zakazić się WZW typu B podczas stosunku seksualnego bez zabezpieczenia?". Większość respondentów kierunku pielęgniarstwo $(74,8 \%)$ potwierdziła możliwość zakażenia HBV w czasie takich sytuacji. Natomiast 7,8\% ankietowanych było przeciwnego zdania. $\mathrm{Z}$ kolei $17,5 \%$ badanych nie potrafiła jednoznacznie odpowiedzieć na powyższe pytanie. 33\% studentów innych kierunków zanegowało sytuację, w której do zakażenia mogłoby dojść podczas stosunku bez zabezpieczenia. Natomiast 53,4 $\%$ ankietowanych potwierdziło, że konsekwencją przygodnego seksu może być zakażenie WZW. Niewielki odsetek badanych $(13,6 \%)$ nie potrafiło udzielić jednoznacznej odpowiedzi.

\section{Dyskusja}

Światowa Organizacja Zdrowia oszacowała, iż w 2015 roku na świecie zakażonych HBV było 257 mln ludzi. Zanotowano 880.000 zgonów z powodu WZW typu B, głównie w wyniku powikłań [5]. WHO w maju 2016 roku na Światowym Zgromadzeniu Zdrowia zatwierdziło Globalna Strategię Sektora Zdrowia (GHSS) dotyczącq wirusowego zapalenia wątroby na lata 2016-2021. Zakłada ona zmniejszenie nowych zakażeń o 90\% i śmiertelności o 65\% [4]. 
W Polsce na przestrzeni ostatnich 20 lat nastąpił spadek zachorowań na wirusowe zapalenie wątroby typu B. Związane jest to z wprowadzeniem $\quad$ w 1989 roku obowiązkowych szczepień ochronnych, a także $\mathrm{z}$ udoskonalaniem procedur higienicznosanitarnych mających na celu przerywanie dróg przenoszenia się wirusa [5].

Polskie Towarzystwo Hepatologiczne opublikowało na swojej stronie Rekomendacje Polskiej Grupy Ekspertów HBV na rok 2018 dotyczące leczenia przewlekłego wirusowego zapalenia wątroby typu B. Wytyczne dotyczą kwalifikacji do leczenia, wyboru optymalnej terapii, monitorowania i czasu trwania leczenia, postępowania w przypadku niepowodzeń terapeutycznych, a także leczenia chorych z towarzyszącą zakażeniu HBV marskością i rakiem wątrobowokomórkowym. Znajdują się tam informacje na temat leczenia zakażeń HBV u dzieci, kobiet planujących ciążę lub będących już $\mathrm{w}$ ciąży oraz wiadomości na temat profilaktyki przedi poekspozycyjnej, zapobieganiu przenoszenia HBV z matki na dziecko, a ponadto o postępowaniu po przeszczepieniu wątroby, podczas immunosupresji i w trakcie leczenia zakażeń HCV [6].

\section{Wnioski}

Niezależnie od zadawanych pytań, respondenci pielęgniarstwa wykazują większą wiedzę w zakresie czynników ryzyka, profilaktyki oraz diagnostyki WZW typu B, niż studenci kierunków pozamedycznych. Zdecydowana większość studentów pielęgniarstwa zdaje sobie sprawę, jak może dojść do zakażenia WZW typu B. Ankietowani wskazują, iż najczęstszą drogą zakażenia jest kontakt z krwią człowieka zakażonego. Wiedza respondentów kierunków pozamedycznych powinna być znacznie podwyższona $\mathrm{w}$ zakresie podstawowych informacji takich jak : czynniki ryzyka oraz profilaktyka. Wśród wszystkich ankietowanych nie brakuje jednak błędnych odpowiedzi dotyczących ryzyka zakażenia wirusem HBV. Największą uwagę należy zatem zwrócić na edukację zdrowotną

$$
-65-
$$


z zakresu zakażeń WZW oraz aktywne uczestnictwo w działaniach profilaktycznych i programach edukacyjnych. Nie należy zapominać o motywowaniu studentów do aktywnego wdrażania założeń profilaktyki zakażeń, udziału $\mathrm{w}$ programach profilaktycznych, aby ograniczyć ryzyko zachorowań na WZW typu B.

\section{Bibliografia/Bibliography:}

1. http://www.czytelniamedyczna.pl/1418,przewlekle-wirusowezapalenia-watroby-typu-b-i-c.html (dostęp z dnia 16.09.2018).

2. http://www.hbv.pl/faq.php\#14 (dostęp z dnia 16.09.2018).

3. http://www.prometeusze.pl/hbv/ (dostęp z dnia 16.09.2018).

4. http://www.who.int/hepatitis/publications/global-hepatitisreport2017/en/ (dostęp z dnia 16.09.2018).

5. Kowalska M. E., Kalinowski P., Bojakowska U. : Profilaktyka wirusowego zapalenia wątroby typu B. Journal of Education, Health and Sport. 2017;7(7):315-321. eISSN 2391-8306.

6. http://www.pasl.pl/ (dostęp z dnia 16.09.2018). 